\title{
Innovation on Mode of General Education of Intellectual Property in Colleges and Universities under the Internet Circumstances
}

\author{
Yu-hong WANG ${ }^{1, a}$, Yin ZHOU ${ }^{2, b,{ }^{*}}$ Yun-feng $\mathrm{LI}^{3, \mathrm{c}}$, Ling $\mathrm{CHEN}^{4, \mathrm{~d}}$ \\ and Rui-rui ZHANG ${ }^{5, \mathrm{e}}$ \\ ${ }^{1,2,3,4}$ Xi'an University of Technology, Xi'an, China \\ awangyuhong@xaut.edu.cn, bzhouyiniris@163.com, '362450347@qq.com, \\ d1191394562@qq.com, '894251059@qq.com
}

Keywords: Intellectual property, General education, Internet.

\begin{abstract}
The wide application of Internet technology and its rapid development has brought the general education of intellectual property in colleges and universities many challenges. According to this paper, the general education mode of intellectual property in colleges and universities characterized by modern education idea and goals as its guidance, scientific education content as its core, multiple education methods and means as its support and high-level teaching staff as its guarantee should be established to promote the development of intellectual property education and the quality of talent cultivation in China.
\end{abstract}

\section{Research Background}

General education of intellectual property in colleges and universities is a kind of comprehensive quality-oriented education that is open to all the college students who are not law majors (including intellectual property major), aiming at cultivating college students' basic knowledge and skills of creating, utilizing, managing and protecting intellectual property by popularizing them the basic knowledge, theory and the existing legal system of intellectual property.

Education mode is a collecting system of educational strategies based on the effective educational practice, including education idea, education objective, education content, education method and other basic elements. Under the circumstances of rapid development of Internet technology, it is of great significance to explore the reform and innovation of general education of intellectual property in colleges and universities. On the one hand, open and convenient Internet as a kind of brand-new information carrying platform provides a new thought, technology and environment for the construction of the innovative general education mode of intellectual property in colleges and universities. Besides, the National Medium and Long-term Education Reform and Development Programming Outline (2010-2020) as well as a series of new national policies such as the Outline of the National Intellectual Property Strategy provides the institutional safeguard for general education of intellectual property in colleges and universities. On the other hand, the Internet technology inevitably poses many challenges to the general education of intellectual property in colleges and universities.

The analysis, taking nearly 1500 undergraduates' questionnaires as samples from five universities in Shaanxi province, shows that in general education of intellectual property widely exist such outstanding problems as backward education idea, unclear education target, outdated education content, simple teaching methods and means and unreasonable teaching staff structure, which have made it completely unable to adapt 
to the demands of social development and talent cultivation in the Internet era. Therefore, it is imperative to reform the existing education mode and establish a more scientific general education mode of intellectual property.

\section{The Establishment of People-oriented and Creative Education Idea with Specific Goals for Talent Cultivation of Intellectual Property}

Idea governs how we act. Social reforms need the change of ideas, so do the education reforms. Under the circumstances of Internet, the change of education idea for general education of intellectual property provides the correct guiding ideology for the implementation of general education in colleges and universities.

First of all, the change of the intellectual property education idea from an utilitarian one to a people-oriented one means the realization of the personal life value combined with social development by changing the past concepts that were too utilitarian and materialistic in educational activities of intellectual property. Intellectual property education should not only be limited to meet the needs of the development of the economy, technology and politics, but also aim at promoting people's all-round development and the coordinated development of the society. Secondly, the education idea should be shifted from carrying only professional education of intellectual property to the equal attention to both professional education and general education of intellectual property. The professional education of intellectual property aims to cultivate professional intellectual property academic or specialized talents, while the general education of intellectual property focuses on cultivating the talents mastering basic knowledge and skills of intellectual property. The importance of general education of intellectual property has been gradually realized and the idea of paying equal attention has been adopted. Thirdly, the change of the education idea should be made from an established and transitive one to an open and creative one, namely from attaching great importance to the intellectual property knowledge of objectivity, universality, publicity to attaching importance to the intellectual property knowledge of intelligibility, contextualization, individuality and creativity. The latter pays attention to both the knowledge acquisition of intellectual property and cultivating college students' abilities of self-study, discovery, invention and critical thinking.

How to define the objectives of the general education of intellectual property in colleges and universities under the circumstances of Internet is directly related to the long-term development of general education, as well as the success or failure of our country's intellectual property strategy implementation. The traditional goals of general education of intellectual property are not closely integrated with the development of Internet, which should be clarified under the circumstances of Internet as follows: let students be familiar with intellectual property theory; understand, accept and respect for intellectual property; abide by the intellectual property laws; set up the idea of respecting knowledge, advocating innovation and keeping integrity; improve the ability of using Internet information resources and technologies to independently create and manage intellectual property.

\section{The Design of Systematic Education Content}

Education content is the core and soul of general education of intellectual property in colleges and universities. First, under the circumstances of Internet, the substantial change of the model of intellectual property creation, utilization, management and protection promotes a reform on IP legal system and an update on general education content in colleges and universities. Second, the traditional general education of the 
intellectual property fails to design related teaching content of intellectual property based on the professional background of the educated and offer the diverse courses for multi-disciplinary students, the teaching content is more designed for the professional talents majoring in intellectual property. Thus few of the educated can really understand, absorb and make use of the intellectual property knowledge on their own. Finally, the traditional education of intellectual property in colleges and universities is lack of practical training, such as the application of patents, the management of intellectual property and the practice of bringing an action against intellectual property infringement, etc.

In the general education of intellectual property, colleges and universities, fully taking advantage of their own resources, should arrange different education contents for students of the different majors to develop general IP talents. First of all, update the general education content of the intellectual property in colleges and universities according to the Internet development and innovation of intellectual property management, legal system and international rules to ensure that education contents keep pace with the times. Secondly, bring the optional courses of intellectual property into education teaching plan in colleges and universities, and the curriculum on intellectual property should be set up to all the students as the compulsory courses. At the same time, give the educated from different majors the priority to practical teaching and special training such as patent applications, copyright protection skills to improve the efficiency of general education of intellectual property. As for engineering college students, the establishment of the related courses such as patent retrieval process can, on the one hand, encourage them to deepen the related professional knowledge, and on the other hand, guide them to carry out the secondary innovation and learn to apply for the patents of their own. Finally, strengthen the combination of theory and practice during the general education of intellectual property. Colleges and universities should make great efforts to cooperate with the practical organizations such as courts and intellectual property agencies to set up long-term practice bases and encourage the educated to practice in related departments to enrich their practical knowledge. They should also invite intellectual property experts to conduct academic lectures to introduce typical cases and the latest development related to application, protection, utilization and management of intellectual property, carry out the innovation contests, competition of science and technology invention and the Internet intellectual property knowledge interlocution among college students to arouse the enthusiasm for the innovation of the educated. Under the circumstances of Internet, the general education of intellectual property in colleges and universities, together with these activities, will obtain better effect.

\section{The Adoption of Heuristic Education Methods and Diversified Education Means}

Due to the limitation of technology, the speed of information transmission was slow and educators might not keep abreast of the learning situation of the educated and get feedback, which led to the short of pertinence of education methods, the backwardness of education means and the less obvious effect in general education of intellectual property in colleges and universities. Educators of traditional general education of intellectual property use cramming education methods. The educated who lack initiative only passively receive knowledge and education. This method has been far from meeting the requirements for college students to improve self-learning ability and innovative quality in Internet era. 
The emergence and widespread use of the Internet provide a new education environment and new education means for general education of intellectual property in colleges and universities. Taking heuristic education methods in stead of cramming education methods has become inevitable. Considering the actual situation of the educated, educators may make use of network resources rationally, inspire minds of the educated, mobilize students' initiative and enthusiasm and instruct them to learn theoretical and practical knowledge related to intellectual property to improve their quality of innovation. Thus the initiative of the educated to acquire knowledge is comprehensively enhanced and the effect of education is also obviously improved.

Multiple advantages of the Internet bring changes to means of general education of intellectual property in colleges and universities. On one hand, Internet can provide multimedia conditions, speedy information transfer and mass information, which the traditional means of education couldn't make use of. On the other hand, educators and the educated can select the relevant knowledge of intellectual property through online interactive interface as needed. Therefore, the learning content is more targeted and focused. The following measures might be taken to renovate the means of general education of intellectual property in colleges and universities: Firstly, adopt multimedia teaching means, vividly presenting the content of general education of intellectual property. Secondly, strengthen the construction of website platform. Distinctive website of general education of intellectual property should be established, intellectual property database be constructed, and online education sectors according to the actual needs of educators and the educated be designed and timely updated in colleges and universities. The mode of general education of intellectual property in colleges and universities under the circumstances of Internet varies from one-to-many communication mode to interactive and communicative teaching mode with various forms which enhances communication between educators and the educated and mobilize the participation and initiative of the educated. Finally, new teaching methods such as MOOCs, microlectures etc. might be introduced in colleges and universities. MOOCs include high-quality course resources from top universities worldwide and are open to all learners at very low cost, the educated can get free access to better education resources of intellectual property on the Internet platform. Microlectures, in the form of the short and micro videos recorded by educators, take the specific knowledge of intellectual property as the core and rely on the Internet platform for the educated to study online. The content is quite concise that can meet the needs of the educated to quickly grasp the knowledge of intellectual property under the circumstances of Internet. According to their own demands or interests, the educated can freely choose the intellectual property courses. At the same time, educators can discover the interests of educators and more suitable education methods and understand the learning and thinking habits of the educated from MOOCs, which make educators better communicate with the educated and complete teaching tasks. Through holding various forms of contest in microlectures, educators can share resources, education idea, education thoughts, education methods and education achievements with each other.

\section{The Establishment of High-quality Teaching Staff with Reasonable Structure}

Educators occupy the key position in education resources. The level and effectiveness of general education of intellectual property in colleges and universities under the circumstances of Internet depend on the composition and level of teachers to a large extent. Under the circumstances of Internet, educators should not only have 
comprehensive knowledge and skills of intellectual property, but also keep pace with the times and constantly expand and acquire new knowledge and new skills. At present, teaching staff in colleges and universities lack structural diversity, and most of the educators of general education of intellectual property are full-time teachers, whose practical experience in intellectual property is relatively limited. Meanwhile, it is difficult for intellectual property agents, lawyers and intellectual property managers engaged in the practical work of intellectual property to become part-time teachers in reality.

Upholding the principle of combination of training and introducing talents, colleges and universities should gradually establish a team of high-quality teaching staff on general education of intellectual property with strong sense of modern education and global awareness, professional knowledge, practical experience of intellectual property, and the ability of information processing. In terms of faculty training, training programs should be formulated that colleges and universities might work together with intellectual property management authorities and agencies to implement; formal education should also be combined with in-service continuing education to train the educators who badly need to update their knowledge system and improve their information technology level. In terms of optimization of faculty structure, according to the modern education theory, colleges and universities should not only introduce interdisciplinary high-quality intellectual property talents and engage intellectual property agents and lawyers with both theoretical and practical experience, but also learning from foreign experience, employ experienced or outgoing officials of government and intellectual property management authorities to further general education of intellectual property in colleges and universities, and to ensure the combination of teaching theory and practice from the aspect of faculty construction.

\section{Conclusion}

To respond to the challenges brought by Internet to higher education, such an innovative general education mode of intellectual property should be established in colleges and universities, characterized by the idea of people-oriented, open, creative education and combination of professional education with general education as its guidance, the cultivation of the general talents of intellectual property as its objective, the systematic education content of connecting theory with practice as its core, heuristic education methods and diversified education means as its support, and the reasonable structure and high-level teaching staff as its guarantee.

\section{Acknowledgement}

This research was financially supported by Project of the Key Research Base on Philosophy and Social Sciences in Colleges and Universities of the Department of Education in Shaanxi Province (14jz028), Shaanxi Soft Science Research Project (2016KRM098), Xi'an Soft Science Research Project (SF1503(1)) and Teaching Research Project of Xian University of Technology (xjy1510).

\section{References}

[1] Yu Yan, Education and Occupation, vol. 29, pp. 119, 2011, in Chinese

[2] Qu Dawei, Zhao Fuzheng, Higher Education Research and Practice, vol. 9, pp. 12, 2015, in Chinese 
[3] Tan Zuojun, Xiao Xiangping, Jiangsu Higher Education, vol.1, pp.77, 2015, in Chinese.

[4] Zhang Mingzhu, Chinese University Technology, vol.8, pp.61, 2011, in Chinese.

[5] Zhang Yan, China Higher Education Research, vol.2, pp.71-72, 2016, in Chinese 